\title{
Pengaruh Gigi Impaksi Molar Ketiga terhadap Ketebalan Angulus Mandibula Berdasarkan Jenis Kelamin
}

\author{
Hendri Poernomo \\ Bagian Bedah Mulut Fakultas Kedokteran Gigi, Universitas Mahasaraswati Denpasar, Bali, Indonesia \\ JI. Kamboja 11A, Denpasar, Bali, Indonesia; e-mail: hendri_poernomo@yahoo.co.id
}

\begin{abstract}
ABSTRAK
Fraktur mandibula sering terjadi pada praktek kedokteran gigi. Fraktur biasanya terjadi di daerah angulus mandibula tepat di daerah yang terdapat gigi impaksi. Masalah yang ditimbulkan akibat fraktur mandibula, yaitu hilangnya keseimbangan, terputusnya komponen neurovascular dan cedera pada jaringan disekitar fraktur. Tujuan dari penelitian ini adalah untuk mengetahui adanya perbedaan ketebalan tulang angulus mandibula antara kelompok yang memiliki gigi impaksi dengan kelompok yang tidak memiliki gigi impaksi serta jenis kelamin berdasarkan radiografis. Jenis penelitian deskriptif analitik menggunakan 40 sampel foto rontgen panoramik. Hasil penelitian terdapat perbedaan rata-rata antara pasien yang memiliki gigi impaksi dan tanpa gigi impaksi yaitu 1,44. Pada pasien impaksi gigi molar ketiga menurut jenis kelamin menunjukkan perbedaan rerata ketebalan angulus mandibula sebesar 1,19 pada laki-laki dan 1,16 pada perempuan serta pasien tanpa impaksi menunjukkan nilai rerata ketebalan angulus mandibula sebesar 1,48 pada laki-laki dan 1,40 pada perempuan. Berdasarkan perhitungan T-test terdapat perbedaan yang bermakna $(\rho<0,05)$. Kesimpulan bahwa adanya perbedaan signifikan ketebalan angulus mandibula pada pasien dengan gigi impaksi molar ketiga rahang bawah dan kelompok pasien tanpa gigi impaksi molar ketiga rahang bawah, serta jenis kelamin.
\end{abstract}

Maj Ked Gi Ind. Juni 2015; 1(1): hal 47-52

Kata kunci: Angulus mandibula, kelompok impaksi, kelompok tanpa impaksi, jenis kelamin

\begin{abstract}
Effect of impacted teeth on thickness of the angle of mandible based on gender. Mandibular fractures often occur in dental practice. Fractures usually occur in the angle of the mandible within the area of the impacted tooth. Some problems that are caused by mandibular fractures area are, the loss of balance, the breaking of neurovascular components and injury to the tissue surrounding the fracture. The purpose of this study is to determine the differences in bone thickness of the angle of the mandible between the groups that have an impacted tooth with the group that does not have an impacted tooth with different gender based on radiographic. This analytic descriptive study used 40 samples of panoramic radiographs. The study results show that the average difference between patients that have impacted tooth with patients that do not have is 1,44. Patients with impacted third molar based on gender show an average difference of the thickness of mandibular angle of 1,19 for men and 1,16 for women and patients with no impaction show an average thickness of the mandibular angle of 1,48 for men and 1,40 for women. Based on T-test calculation, there is a significant difference $(\rho$ <0.05). The conclusion of study is that there is significant differences in the thickness of the angle of the mandible based on group of patients with impacted mandibular third molar, with the group of patients without impacted mandibular third molar.
\end{abstract}

Maj Ked Gi Ind. Juni 2015; 1(1): hal 47-52

Keywords: Angle of the mandible, group with impaction, group without impaction, gender

\section{PENDAHULUAN}

Fraktur mandibula sering terjadi di daerah angulus mandibula tepat di daerah yang terjadi gigi impaksi. Fraktur terjadi secara tiba-tiba ataupun terjadi pada saat dilakukannya pembedahan di daerah tersebut, oleh karena itu dokter gigi dituntut untuk mengurangi resiko terjadinya fraktur mandibula.

Mandibula adalah tulang rahang bawah manusia dan berfungsi sebagai tempat menempelnya gigi geligi rahang bawah. Mandibula berhubungan dengan basis cranial melalui temporo-mandibular joint dan disangga oleh otot-otot pengunyah. ${ }^{1}$ Fraktur mandibula dapat terjadi karena tekanan yang cukup besar yang mengakibatkan tulang mandibula menjadi fraktur, biasanya pada daerah yang secara anatomis relatif lemah. Akibat langsungnya adalah hilangnya keseimbangan, terputusnya komponen neurovascular dan cedera pada jaringan di sekitar fraktur. ${ }^{2}$

Pencabutan gigi molar ketiga membutuhkan perencanaan dan ketrampilan bedah yang memadai. Dalam literatur, diungkapkan frekuensi komplikasi setelah pencabutan gigi molar tiga 
berkisar antara 2,6\% sampai 30,9\%. Spektrum komplikasi berkisar antara efek samping yang tidak berbahaya seperti nyeri dan pembengkakan sampai kerusakan saraf, fraktur mandibula dan infeksi yang membahayakan. ${ }^{3}$

Penelitian biomekanis dan epidemologi mendukung hipotesis bahwa keberadaan molar ketiga berhubungan dengan peningkatan resiko fraktur pada angulus mandibula karena terjadi kehilangan kualitas dan kekuatan tulang pada daerah ini. Gejala ini paling nyata ketika molar ketiga mengalami impaksi, sedangkan keparahan impaksi dan letak gigi tersebut memiliki sedikit pengaruh terhadap fraktur angulus mandibula. ${ }^{4}$

Radiografi merupakan salah satu metode yang dapat digunakan untuk mendiagnosis dan menentukan letak anatomi jaringan rongga mulut. ${ }^{5}$ Ketepatan pengukuran radiografi yang objektif merupakan faktor penting untuk memperoleh diagnosis serta penentuan rencana perawatan dengan tepat. ${ }^{6}$ Foto rontgen ini dapat digunakan untuk mengevaluasi gigi impaksi, pola erupsi, pertumbuhan dan perkembangan gigi geligi, mendeteksi penyakit dan mengevaluasi trauma. Kata lain radiografi panoramik merupakan pemeriksaaan yang memperlihatkan keadaan serta hubungan maksila dan mandibula secara keseluruhan. ${ }^{5}$ Oleh karena itu, seorang dokter gigi harus mengerti dan memahami anatomi dalam rongga mulut agar tidak terjadi kekeliruan dalam melakukan suatu pencabutan gigi impaksi.

Mandibula merupakan tulang terkuat dan terbesar pada tulang wajah berbentuk seperti tapal kuda (dengan gigi geligi rahang bawah) dan ramus. Tulang mandibula memiliki permukan anterior dan posterior dan memiliki batas superior dan inferior. Berbatas dengan garis tengah, permukaan anterior terdapat tonjolan triangular berupa protuberansia mentale pada tulang dagu. Bagian yang cekung ke dalam dinamakan fossa mentalis, terletak sebelah lateral pada daerah mentalis, terletak pada permukaan lateral mandibula, di bagian inferior premolar kedua, batas tengah diantara bagian bawah tulang mandibula dan ridge alveolar. ${ }^{7}$

Angulus mandibula adalah permukaan antara tepi belakang ramus mandibula dan tepi bawah korpus mandibula. Secara ekstra oral terletak subkutan dan mudah diraba pada dua sampai tiga jari dibawah lobus aurikularis. Angulus mandibula adalah wilayah segitiga yang dibatasi oleh perbatasan anterior dari otot masseter dengan lampiran posterior dari otot masseter. ${ }^{8}$

Fraktur mandibula menguntungkan ketika otot cenderung menarik fragmen tulang bersama-sama dan tidak menguntungkan ketika fragmen tulang dipisahkan oleh otot. Patah tulang ini cenderung terjadi di daerah body. ${ }^{8}$ Fraktur angulus mandibula terjadi di wilayah segitiga antara perbatasan anterior masseter dan penyisipan posterosuperior dari masseter dan terjadi di distal molar ketiga. ${ }^{8}$

Pada prinsipnya gigi impaksi adalah gigi yang tidak dapat erupsi seluruhnya atau sebagian karena tertutup oleh tulang atau jaringan lunak atau keduanya. ${ }^{9}$ Semua jenis gigi memiliki kemungkinan untuk tidak dapat tumbuh, paling sering terjadi pada gigi molar ketiga rahang bawah dan rahang atas, gigi kaninus dan gigi premolar. Pada umumnya gigi molar ketiga akan tumbuh menembus gusi pada awal usia 18-20 tahun, karena 28 gigi permanen lainnya sudah tumbuh keseluruhannya, sehingga gigi molar ketiga seringkali tidak memperoleh cukup tempat untuk tumbuh karena tertahan oleh gigi molar kedua didepannya. Keadaan semacam ini dikenal dengan sebutan gigi tertanam atau gigi impaksi. ${ }^{10}$

Gigi molar ketiga rahang bawah impaksi dapat menggangu fungsi pengunyahan dan sering menyebabkan berbagai komplikasi sehingga perlu dilakukan tindakan pencabutan. Upaya pengeluaran gigi impaksi terutama pada gigi molar ketiga rahang bawah dilakukan dengan tindakan pembedahan yang disebut dengan odontektomi. ${ }^{11}$

Peranan foto rontgen sangat besar, diantaranya dalam membantu menentukan macam dan rencana perawatan yang akan dilakukan. Banyak macam cara pemeriksaan foto rontgen dibidang kedokteran gigi, antara lain: intra oral meliputi periapikal, bite wing, oklusal dan ekstra oral meliputi panoramik, waters, TMJ, postero anterior. ${ }^{12}$

Gambar radiografi panoramik memberikan gambaran kondilus, ramus, dan badan mandibula dalam satu foto. Gambaran ini biasanya penting 
untuk mengevaluasi kondilus yang mengalami erosi tulang yang luas, pertumbuhan atau patahan dari fraktur kondilaris dan subkondilaris pada kedua sisi sehingga bisa langsung dilakukan perbandingan antara kondilus kanan dan kiri. Hal ini sangat bermanfaat untuk mendiagnosa fraktur kondilus. ${ }^{12}$

Coreldraw adalah salah satu editor grafis yang berbasis vector yang dibuat oleh corel, sebuah perusahaan perangkat lunak yang bermarkas di Ottawa Kanada. Beberapa aplikasi yang ada diantaranya, adalah Quick start, table, smart drawing tools, save as template, dan lain sebagainya. ${ }^{13}$

Operasi dasar dari coreldraw $x 6$, objek garis pada sistem coreldraw dapat dibentuk melalui curve tool yang ada pada fasilitas toolbox. Adapun subalat pada fasilitas curve tool berupa, Freehand tool, Bezier tool, Artistic media tool, Pen tool, Polyline tool, 3 point curve tool, Connector tool, Dimension tool. ${ }^{13}$

Permasalahannya adalah apakah ada perbedaan ketebalan tulang angulus mandibula pada kelompok yang memiliki gigi molar ketiga impaksi dengan kelompok yang tidak memiliki gigi impaksi molar ketiga dan berdasarkan jenis kelamin dilihat secara radiografis.

\section{METODE PENELITIAN}

Jenis penelitian yang dilakukan menggunakan analitik deskriptif dengan pendekatan cross sectional. Jenis penelitian yang dilakukan menggunakan analitik deskriptif dengan pendekatan cross sectional dan sampel yang digunakan sebanyak 80 rontgen foto panoramik dengan teknik pengambilan sampel dilakukan secara stratified random sampling pada pasien yang memiliki atau tanpa gigi impaksi molar ketiga rahang bawah di RSGM FKG Unmas Denpasar.
Jalannya penelitian sampel penelitian berupa hasil radiografi dengan proyeksi panoramik dikumpulkan kemudian sampel dipilah berdasarkan kelompok keadaan gigi molar ketiga bawah yang impaksi dengan tidak impaksi dan jenis kelamin. Hasil radiografi panoramik diperiksa dan dibaca pada komputer menggunakan program Corel Draw $X 6$, dilanjutkan menentukan sumbu vertikal (titik $A$ ), yaitu membuat titik di processus condylaris sejajar dengan tepi kiri ramus mandibula, sumbu horizontal (titik B), yaitu membuat titik di protuberantina mentalis sejajar dengan tepi tulang body, menentukan titik $C$ yang merupakan garis pertemuan titik $A$ dan titik $B$. Menentukan garis horizontal dengan titik sumbu $D$, yaitu membuat titik di processus coronoideus sejajar dengan tepi kanan ramus mandibula dilanjutkan menentukan garis vertikal dengan titik sumbu $\mathrm{E}$ dengan membuat titik tepat di garis median di kontak oklusi gigi bawah sejajar dengan kontak oklusi gigi bawah dan pertemuan titik $D$ dan titik $E$ dinamakan titik $F$. Setelah hubungan titik $C$ dan $F$ diperoleh, tarik garis sejajar dengan titik tersebut. ${ }^{4}$ Garis diukur dengan menggunakan Corel Draw X6 dan hasil pengukuran di catat pada form penelitian. Data yang diperoleh dianalisis menggunakan independent T-Test. nilai signifikansi 0,05.

\section{HASIL PENELITIAN}

Penelitian mengenai ketebalan tulang angulus mandibula berdasarkan radiografi pada pasien RSGM FKG Universitas Mahasaraswati Denpasar diperoleh hasil uji statistik, sebagai berikut. (lihat Tabel 4.1, 4.2, 4.3). Berdasarkan Tabel 4.1 sampel radiografi panoramik yang berjumlah 80 , terdiri atas 40 sampel impaksi yang memiliki rata-rata sebesar 1,177 dan 40 sampel tanpa impaksi yang memiliki rata-rata sebesar 1,441 .

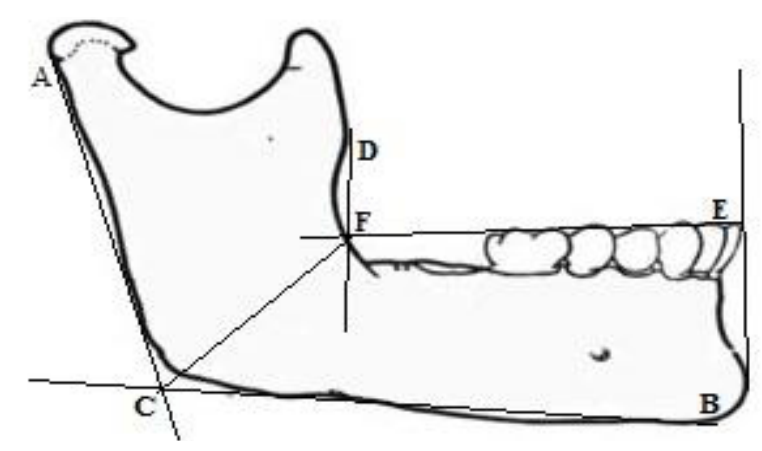

Gambar 3.1 Cara mengukur proyeksi ketebalan angulus ${ }^{4}$ 
Berdasarkan Tabel 4.2 sampel radiografi panoramik yang berjumlah 80 , terdiri atas 40 sampel impaksi menunjukkan nilai rerata ketebalan angulus mandibula sebesar 1,193 pada 20 orang laki-laki dan 1,162 pada 20 orang perempuan serta 40 sampel tanpa impaksi menunjukkan nilai rerata ketebalan angulus mandibula sebesar 1,480 pada 20 orang laki-laki dan 1,403 pada 20 orang perempuan.

Setelah data berdistribusi normal dan homogen dilanjutkan uji Independent T-Test untuk data impaksi maupun tanpa impaksi dan data jenis kelamin. Dari analisis data Independent T-test diperoleh hasil seperti pada Tabel 4.3 dapat dilihat bahwa nilai signifikansi adalah $<0,05$, artinya bahwa ada perbedaan antara rata-rata ketebalan angulus mandibula berdasarkan kelompok impaksi dan tanpa impaksi. Begitu pula dengan kedua rerata ketebalan angulus mandibula berdasarkan jenis kelamin laki-laki dan perempuan terdapat perbedaan yang bermakna.

\section{PEMBAHASAN}

Hasil penelitian terhadap ketebalan tulang angulus mandibula berdasarkan keadaan gigi molar ketiga menunjukkan terdapat perbedaan rerata ketebalan tulang. Seperti yang dapat dilihat pada Tabel 4.1 dimana rerata ketebalan tulang angulus mandibula pada pasien yang memiliki gigi impaksi molar ketiga rahang bawah di kedua sisi, yaitu $1,177 \mathrm{~mm}$ sedangkan rerata ketebalan tulang angulus mandibula pada pasien yang tidak memiliki gigi impaksi molar ketiga di kedua sisi, yaitu $1,441 \mathrm{~mm}$ sehingga diperoleh selisih sebesar $0,264 \mathrm{~mm}$. Hal ini terjadi karena hilangan kualitas dan kekuatan tulang pada daerah ini. Kejadian ini paling nyata ketika molar ketiga mengalami impaksi, sedangkan keparahan impaksi dan letak gigi tersebut memiliki sedikit pengaruh terhadap fraktur angulus mandibula. ${ }^{4}$

Tabel 4.1 Hasil uji rerata (dalam $\mathrm{mm}$ ) ketebalan tulang angulus mandibula berdasarkan keadaan gigi molar ketiga

\begin{tabular}{lccccc}
\hline & Gigi & N & Mean & SD & Std. Error Mean \\
\hline \multirow{2}{*}{ Skor } & Impaksi & 40 & 1,177 & 0,049 & 0,007 \\
& Tanpa impaksi & 40 & 1,441 & 0,077 & 0,012 \\
\hline
\end{tabular}

Keterangan Tabel:

$\mathrm{N}$ : Jumlah sampel

SD : Standar Deviation

Tabel 4.2 Hasil uji rerata (dalam $\mathrm{mm}$ ) ketebalan tulang angulus mandibula berdasarkan jenis kelamin

\begin{tabular}{lcccc}
\hline & Jenis kelamin & N & Mean & SD \\
\hline \multirow{2}{*}{ Impaksi } & laki-laki & 20 & 1,193 & 0,052 \\
& Perempuan & 20 & 1,162 & 0,042 \\
\multirow{2}{*}{ Tanpa impaksi } & laki-laki & 20 & 1,480 & 0,069 \\
& Perempuan & 20 & 1,403 & 0,066 \\
\hline
\end{tabular}

Keterangan Tabel:

$\mathrm{N}$ : Jumlah sampel

SD : Standar Deviation

Tabel 4.3 Hasil uji Independent T-Test terhadap ketebalan angulus mandibula

\begin{tabular}{llcccc}
\hline \multirow{2}{*}{ Impaksi } & Jenis kelamin & $\mathrm{t}$ & $\mathrm{sig}$ & Mean difference & Rerata \\
& Laki-laki & 2,097 & 0,043 & 0,03150 & 1,1935 \\
& Perempuan & 2,097 & 0,043 & 0,03150 & 1,1620 \\
& Laki-laki & 3,612 & 0,001 & 0,07750 & 1,4805 \\
& Perempuan & 3,612 & 0,001 & 0,07750 & 1,4030 \\
\hline
\end{tabular}

Keterangan Tabel:

T: T-test

Sig: significant 
Hasil pengukuran terhadap ketebalan angulus mandibula berdasarkan jenis kelamin terlihat perbedaan rerata pada masing-masing kelompok. Seperti yang dapat dilihat pada Tabel 4.2 dimana rerata ketebalan angulus mandibula pada pasien laki-laki yang memiliki gigi impaksi, yaitu 1,193 $\mathrm{mm}$ sedangkan rerata ketebalan tulang angulus mandibula pada pasien perempuan yang memiliki gigi impaksi, yaitu $1,162 \mathrm{~mm}$ terdapat perbedaan $0,031 \mathrm{~mm}$. Begitu pula dengan kelompok yang tidak memiliki gigi impaksi rerata ketebalan tulang pada laki-laki, yaitu $1,480 \mathrm{~mm}$ dan rerata pada perempuan, yaitu $1,403 \mathrm{~mm}$ jadi terdapat selisih rerata sebesar $0,077 \mathrm{~mm}$. Penurunan ketebalan tulang kortikal ditemukan pada angulus mandibula, yang diukur dalam radiograf panoramik dan dibandingkan antara laki-laki dan perempuan. Hasil ini juga menunjukkan bahwa kepadatan mineral tulang berkurang dapat mengubah bentuk tulang, dan menyebutkan bahwa osteoporosis mandibula juga berhubungan dengan perubahan tulang angulus mandibula. ${ }^{4}$ Wanita usia 70 tahun mengalami $50 \%$ resorbsi tulang angulus mandibula dan mencapai sekitar $100 \%$ resorbsi pada usia 90 tahun. ${ }^{14}$ Hasil penelitian lain menyatakan bahwa rata-rata ketebalan tulang angulus mandibula lebih besar pada pria dibandingkan pada wanita. ${ }^{15}$

Hasil pengukuran ketebalan angulus mandibula berdasarkan jenis kelamin menggunakan Independent T-test terlihat hasil yang signifikan pada masing-masing kelompok. Seperti yang dapat dilihat pada Tabel 4.3 dimana nilai signifikan pada kelompok yang memiliki gigi impaksi molar ketiga rahang bawah pada laki-laki yaitu 0,043 dan pada perempuan yaitu 0,043 . Nilai signifikan pada kelompok yang tidak memiliki gigi impaksi molar ketiga rahang bawah pada laki-laki yaitu 0,001 dan pada perempuan yaitu 0,001 . Dapat dilihat nilai signifikan adalah $<0,05$, itu artinya terdapat perbedaan yang signifikan terhadap ketebalan tulang angulus mandibula berdasarkan gigi impaksi dan tanpa impaksi molar ketiga rahang bawah dilihat pada jenis kelamin. Penelitian sebelumnya pada 1210 pasien, menunjukkan bahwa pada pasien yang memiliki gigi impaksi molar ketiga rahang bawah terjadi fraktur angulus mandibula lebih dari 2 kali lipat dibandingkan dengan pasien yang tidak memiliki gigi impaksi molar ketiga. ${ }^{16}$
Berdasarkan penelitian ini, maka dapat diketahui bahwa ada perbedaan ketebalan angulus mandibula berdasarkan kelompok keadaan gigi impaksi dan jenis kelamin, ini berarti diperlukan teknik khusus dalam melakukan pengambilan gigi impaksi molar ketiga rahang bawah pada laki-laki maupun pada perempuan. Dengan mengetahui ketebalan tulang angulus mandibula maka kegagalan dalam pencabutan gigi impaksi dapat diminimalisir. Hasil penelitian menunjukkan ketebalan angulus mandibula pada gigi impaksi yaitu 1,10-1,29 $\mathrm{mm}$ dan hasil penelitian menunjukkan ketebalan angulus mandibula pada gigi tanpa impaksi yaitu 1,32-1,57 mm dengan demikian diperlukan teknik khusus pada pengambilan gigi impaksi molar ketiga rahang bawah yaitu dengan teknik odontektomi parsialis.

\section{KESIMPULAN}

Berdasarkan hasil penelitian dan pembahasan dapat disimpulkan bahwa terdapat perbedaan ketebalan angulus mandibula antara kelompok pasien gigi impaksi dengan tanpa gigi impaksi molar ketiga rahang bawah serta jenis kelamin yang bermakna. Dengan mengetahui ketebalan tulang angulus mandibula maka kegagalan dalam melakukan odontektomi dapat diminimalisir dan dihindari.

\section{DAFTAR PUSTAKA}

1. Pearce EC. Anatomi dan Fisiologi untuk Paramedis, ed. Ke-32, Jakarta: PT. Gramedia Pustaka Utama; 2009.

2. Pedersen GW. Buku Ajar Praktis Bedah Mulut (Oral Surgery), Ed. Ke-1, Jakarta: EGC; 1996.

3. Hapsari DR. Komplikasi langka akibat pembedahan gigi molar ketiga, Terjemahan Jurnal Bedah Mulut. 2009; 8: 11-14.

4. Watanabe PCA, Alonso MBCC, Monterio SAC, Tiossi R, Issa JPM. Morphodigital study of bone quality in the mandibular angle in patiens with third molar impacted, Japanese Association Of Anatomis. 2009; 84: 246-252. 
5. Afsar A, Haas DA, Rossouw E, Wood RE. Radiographic localization of mandibular anesthesia landmarks. J. Oral Surg. Oral Med. Oral Pathol. Oral Radiol. Endod. 1998; vol. 86; H. 234.

6. Hanna BL, Menik P, Budi Utomo, Susworo R. Converting conventional radiographic examination data of trabecular bone pattem values into density measurement values using intraoral digital images, J. Oral Radiology, 2009; 25: 2: 129-134.

7. Tedyasihto B. Buku Ajar Implantologi Mulut Teori dan Praktek, Jakarta: EGC; 2012.

8. Barrera JE. Mandibular Angle Fractures [Homepage of medscape], [Online]. Available: emedcine.medscape.com/article/868517overview\#a0103 [18 Juni 2013].

9. Firmansyah D, Iman TS. Fraktur patologis mandibula akibat komplikasi Odontektomi gigi molar ketiga bawah, Indonesian Journal of Dentistry, 2008; 15: 3: 192-195

10. Ceon PD. Operasi Gigi Geraham ke-3 Tertanam (Wisdom Tooth Removal) [Homepage of coenpramonoprof], [Online]. Available: coenpramonoprof.com /pages/ operasi-gigi-geraham-ke-3-tertanam-wisdomtooth-removal.html [19 Februari 2013].
11. Dwipayanti A, Adriatmoko W, Rochim A. Komplikasi post Odontektomi gigi molar ketiga rahang bawah impaksi, Jurnal PDGI, 2009; 58: 2: 20-24.

12. Epsilawati L, Firman RN. Diagnosa kelainan sendi temporomandibular dengan memanfaatkan panoramik foto, Majalah Kedokteran Gigi Universitas Padjajaran, 2011; 2: 39-44.

13. Wikipedia.Coreldraw Indonesia Available from: http://community. coreldraw.com/ collaborate/w/language/coreldrawindonesia. 2012.

14. Ardakani, WL, Niafar N. Evaluation of changes in the mandibular angular cortex using panoramic images, J. Contemp. Dental Pract, 2004; 5: 1-15.

15. Xie $\mathrm{Q}$, Wolf J, Tilvis R, Ainamo A. Resoprtion of mandibular canal wall in the edentulous aged population, J. Prosthet Dental, 1997; 77: 596-600.

16. Fusilier J.C, Ellis EE, Dodson TB. Do mandibular third molars alter the risk of angle fracture?, J. Oral MaxillofacSurg, 2002; 60: 514-518. 